\title{
Business travel and mobile workers
}

\author{
Anne AGUILERA
}

Université Paris Est, INRETS-LVMT, 19 rue Nobel, 77455 Champs sur Marne, France

tel : + 33 (0) 164152102 ; fax : + 33 (0) 1641521 40, e-mail address :

aguilera@inrets.fr 


\title{
Business travel and mobile workers
}

\begin{abstract}
Transportation activity generated by businesses has been analyzed mainly with reference to freight flows and commuting trips. The area of employee business trips has been largely ignored, even though the literature - particularly that dealing with industrial economics - has endeavored to show both the central role played by face-toface encounters in economic contact, and the decreased need for proximity as a prerequisite to such contact taking place in the first place. This paper takes this literature, both theoretical and empirical, as its base, and then aims to gain a more comprehensive understanding of the need for business travel and the profiles of mobile workers. It also investigates how the workers involved perceive, and how companies account for such mobility.
\end{abstract}

\section{Key words}

business travel, mobile workers, face to face, ICT 


\section{Introduction}

Mobility generated by economic activity has previously been analyzed principally in terms of goods transportation and commuting trips (i.e. travel between home and regular place of work). Much less attention has been paid to business travel, defined as work-related travel to an irregular place of work (for example: to visit a client, participate in a conference or attend a meeting, etc.).

Indeed, business travel represents only a limited proportion of personal mobility, accounting, for example, for only $16 \%$ of the long-distance trips (defined as journeys from the home to the furthest destination of 50 miles or more) of American workers in 2002, according to the National Household Survey.

The immediate explanation is that such travel concerns only a minority of workers (Frändberg and Vilhelmson, 2003). The literature, however, underlines that for these mobile workers, this mobility can be a very important and time-consuming aspect of their professional lives (Belton and de Coninck, 2006; Westman and Etzion, 2002). On the one hand, then we should consider business travel as one way in which work has been transformed in our post-industrial society (Barley and Kunda, 2001). On the other, we should analyze business travel as one important element in the functioning of the post-industrial economy. Indeed, much has been written on the crucial aspect of face-toface interactions in today's business relationships (Gaspar and Glaeser, 1998) and the fact that the development of Information and Communication Technologies (ICTs) and transport infrastructure means that business partners can be located almost anywhere in the world (Amin, 2002; Torre and Rallet, 2005). It can therefore be said that a fraction of face-to-face encounters may involve physical travel. 
This paper is based on a review of recent literature, both theoretical and empirical, and aims to reach a better understanding of the need for business travel and the profile of mobile workers. It also investigates how the workers involved perceive, and how companies account for such mobility. The paper is divided into 4 sections and a conclusion.

In sections 1 and 2 , an attempt is made to try and understand why business travel is important in today's economy. We explain why firms have to communicate with and coordinate (in the broadest possible sense) remote locations (section 1) and why, despite the crucial nature of ICTs in the establishment and maintenance of such long-distance relationships, mediated forms of technology often cannot fully replace face-to-face contact (Gaspar and Glaeser, 1998). To a certain extent, then, both intra and inter-firm communication should generate business travel (section 2). Section 3 focuses on the factors that differentiate individual companies and workers in terms of their need for and the nature of, such as distance covered, business travel. Section 4 discusses how workers and companies perceive and account for this mobility. The conclusion summarizes the paper's main findings and identifies some possible areas of future research.

\section{A Growing Need to Communicate with Long-Distance Partners}

The ability to obtain, share, and transmit information, especially complex information, has become highly strategic in the post-industrial economy. Among the principal factors that have produced this need for long-distance communication (in the broadest sense) are: multi-units companies, project team success, and globalization.

\subsection{Multi-units companies and Internal Communication}

The number of companies with more than one office is on the increase. Theorists (Ota and Fujita, 1993) regularly employ the decreased cost of communication 
to explain such changes. This does not, however, mean that multi-units companies do not see communication as important; rather, the internal communication requirements of such companies are determined by the division of labor (specialization versus integration) and the degree of decentralization within the company (Brousseau and Rallet, 1997).

Thus, it is generally agreed that the development of multi-units companies, a flattening of hierarchical structure and increased employee independence have led to an increased need for internal communication, as it is now necessary to broadcast both internal and external information, implement new production procedures, etcetera.

\subsection{Project-teams and Inter-firm Co-operation}

The development of teams dedicated to a project is one major trend in the organization of production, and the literature on this new form of work (also known as distributed teams, innovation teams, etc.) is particularly rich. It shows especially that project-teams frequently involve members in different locations and that there is a strong need for communication between these various members (Hildrum, 2007).

In a more general way, inter-firm relationships (especially co-operations) are developing in a context of increased competition and greater requirements for flexibility, reactivity and constant innovation (Andersson and Karlsson, 2004). Indeed, a quantitative survey of French manufacturing firms has highlighted a significant increase in inter-firm communication between 1987 and 1997 (Charlot and Duranton, 2006). Moreover, many studies have pointed out that firms that co-operate are not necessarily located in the same cluster, but often operate remotely (Andersson and Ejermo, 2005; Bathelt et al., 2004; Rallet and Torre, 2000). 


\subsection{Internationalization of the Market and Client Relationships}

Globalization has led to the expansion of many a company's market: geographical proximity between manufacturer and client is not always a necessity any more. Furthermore, within the context of increased (worldwide) competition, clients are often more demanding, especially regarding delivery dates, quality standards and personalization (Ughetto et al., 2002) and therefore result in increased communication. Data from the French manufacturing sector has underlined the significant development in customer communication between 1987 and 1997 (Charlot and Duranton, 2006). The service sector is also directly concerned, in that client coordination needs, during both the planning and production processes, are often intense (Aguiléra, 2003; Wickström, 1995).

The combination of these two trends (increased communication with the customers and market expansion) may play a role in the development of long-distance business travel.

\section{The maintained importance of face-to-face contacts in work relationships}

Part 1 suggests that we can reasonably hypothesize that many companies (or, more generally speaking, many organizations) face an increased need to communicate with remote partners. However, this does not necessarily means that physical travel is required: many relationships can be conducted through mediated communications (telephone, email, videoconference, etc.). To understand the need for business travel, we should now investigate the conditions under which face-to-face contacts remain necessary.

The development of ICTs and transportation infrastructure (and the associated decrease in transportation costs) make it possible to stay in contact with remote partners: on the one hand, some kinds of relationships require no, or next to no, face-to- 
face encounters; others, often more complex or strategic, can be maintained through a combination of mediated communications (telephone, email, videoconference, etc.) and (less numerous) face-to-face meetings (Urry, 2002).

The second part of this paper will focus on this second kind of relationship, because they imply that partners can be remotely located but maintain relationships, particularly by traveling more or less frequently.

\subsection{The Nature of Communication: Tacit versus Codified Knowledge}

The main reason for choosing a means of communication is the nature of the knowledge to be exchanged. The literature traditionally distinguishes between tacit and codified knowledge. Although this dichotomy has often been criticized, we consider it provides interesting framework by which we might understand the connection between the nature of knowledge and the way it can be communicated (Balconi et al., 2007). It can also explain why so much research concludes that no communications technology (or mixed use of communication technologies) can fully compensate for the richness of face-to-face contacts, in cases, for example, such as the conveyance of complex, nonstructured, or potentially ambiguous information (Boden and Molotch, 1994; Larsen et al., 2007). Even videoconferencing is often criticized, and is not seen as an entirely satisfactory alternative to face-to-face contact (Lorentzon, 2003).

Codified knowledge is explicit knowledge that can be communicated through ICTs. The definition proposed by B.A. Lundvall and B. Johnson (1994) is more precise, placing codified knowledge into two categories: knowledge about facts (know-what) and knowledge about principles and laws (know-why). Tacit knowledge, on the other hand, cannot be transmitted via mediated communication, but rather requires face-toface interaction. It refers to both competence and skills (know-how) and to information about who knows what and who knows how to do what (know-who). 
Empirical facts tend to confirm this assumption. In their analysis of intercompany cooperation in France, V. Lethiais and A. Aguiléra (2007) have demonstrated that the frequency of face-to-face contact is positively correlated to the share of knowledge about competence and skills (know-how). In Norway, J.I. Lian and J.M. Denstadli (2004) have highlighted that negotiations with clients made up a significant proportion of face-to-face meetings simply because such negotiations entail complex forms of communication. In his study of information exchange in companies of various sizes, S. Lorentzon (2003) concludes that face-to-face contact is necessary to the transmission of unstructured or informal information. S. Charlot and G. Duranton (2006), in their analysis of workplace communications data in a representative sample of French manufacturing firms, argue that only complex information has to be exchanged face-to-face. They also suggest that developments in ICTs (such as videoconferencing, email, etc.) led to the use of face-to-face contact for only the "most complex" interactions between 1987 and 1997.

\subsection{Addition explanations for the need for face-to-face encounters}

The choice of a means of communication not only depends on the nature of information that has to be transmitted, and face-to-face encounters may be preferable even in cases concerning knowledge that could have been transmitted via ICTs.

The kind of communications system being used by the interlocutors should not be ignored, nor their familiarity with such means. Face-to-face contacts have been proven to be more important than ICTs when workers have no access to or are not familiar with the Internet (Lethiais and Aguiléra, 2007).

Secondly, geographical proximity between the interlocutors can make face-toface contacts more frequent, even if the information could have been transmitted by ICTs (Rallet and Burmeister, 2002). The research of V. Lethiais and A. Aguiléra (2007) 
confirms this empirically: the authors have pointed out that the nature of knowledge, and more precisely the exchanging of tacit knowledge, is directly linked to the relative importance of face-to-face interaction only when the people concerned are not located within the same region. In other words, if they are located in the same geographic area, the relative frequency of face-to-face contacts does not depend on whether their communication concerns tacit or codified knowledge.

Thirdly, as B. Arnfalk and P. Kogg (2003) suggest, face-to-face meetings are often preferable when meetings involve persons external to the firm, even if such meetings could have been handled via ITCS: physical presence can be considered to be a sign of interest.

Fourthly, face-to-face contact is necessary to create mutual trust and other such interpretive skills. In other words, face-to-face meetings that occur at the beginning of a business relationship can make mediated communication more efficient during the project's course (Gallaud and Torre, 2005; Vecchi and Wickham, 2006). Indeed, remote teamwork is generally easier when interlocutors know and trust each other (Gallié and Guichard, 2005). Therefore, as much empirical research has argued, even "virtual" teams need face-to-face encounters (Arnfalk and Kogg, 2003; Handy, 1995; Kirkman et al. 2004).

We should also mention the significant incentives provided by frequent flyer programs, opportunities for tourism (Hoyer and Naess, 2001; Van Trommel et al., 1998) or visiting relatives and friends (Larsen et al., 2007) to choose to travel over mediated forms of communication.

\subsection{Training and Information Needs and the Production of Business Travel}

The growing need to attend conferences, trade shows (Ramirez-Pasillas, 2006), and courses is another important factor in the production of business travel. According 
to the 1994 Travel Survey (the most recent National Survey available), courses, conferences and conventions represented $23 \%$ of long-distance business travel in France in that year. For the Norwegian employees (traveling by air) interviewed by I. Lian and J.M. Denstadli (2004), 42\% of domestic business travel was due to conferences, courses and conventions. In Sweden, about one fifth of long-distance business trips (exceeding $100 \mathrm{~km}$ one way) are motivated by conferences and other events, whereas meetings, customer visits, etc. represent about one half (Frändberg and Vilhelmson, 2003). Moreover, this share increases, as distance becomes more of a factor: from $17 \%$ of domestic long-distance business trips to $22 \%$ of international very long-distance trips (exceeding $1000 \mathrm{~km}$ one way).

\section{Business travel: Differences between Companies, Differences Among Workers}

In the two previous sections of this paper, we have discussed general determinants that may explain the need for business travel. We have, however, considered companies (or, more generally, organizations) as a whole, and have not made any distinctions between the workers involved. Yet business travel may vary greatly from one firm to another and from one worker to another, in terms of amount, frequency, geographical patterns, etc. We will now discuss these variations.

\subsection{Elements that Differentiate Between Companies}

\subsubsection{Sector and size}

Do usual parameters like sector and size differentiate between companies in terms of the quantity of business travel they conduct? Empirical studies show different results. P. Hugoson (2001) finds that the willingness to make a business trip increases with the size of the firm, and is greater in the manufacturing industry than in others. In Norway, J.I. Lian and J.M. Denstadli (2004) conclude that the oil industry produces more mobility than other sectors. P. Haynes et al. (2005) suggest that the software 
industry is one of the most travel-intensive sectors in Ireland. On the other hand, V. Lethiais and A. Aguiléra (2007)'s study of companies in Brittany, France, concludes that there is relationship between the sector or size of a company and its frequency of business travel.

An explanation for such contradictory findings probably lies in the observation that a company's sector or size is not the most appropriate parameter by which a need for business travel should be judged. Organizational parameters (in their broadest sense) are undoubtedly far more determining, as we discuss below.

\subsubsection{Organizational aspects}

This very general term designates a great many organizational elements that characterize companies and their business activity, both at the internal and external levels. Particularly relevant here are the existence of diverse units, their number, and their geographical distribution, as well as how the company organizes production between these units and technical elements such as the communications system between units. How a company organizes its work - particularly when it comes to the existence or not of project teams - is another important factor. On an external level, this would include factors such as the number of partners a company has, how it communicates with those partners, their location and their relationship with clients, etc. It is how such characteristics are related to the production of business travel within a company that is the question here. Reviewing the literatures provides some answers, but there is still a lot of research to do in order to better understand the relationship between organizational patterns and the production of business travel (Haynes et al., 2005).

The number of interlocutors seems to lessen the frequency of face-to-face contact, especially if those interlocutors are remote: V. Lethiais and A. Aguiléra (2007) have argued that, all else being equal, the more co-operation projects a company is 
involved in, the less likely it is to plan face-to-face meetings. Probably the cost of travel is one reason to limit the number of face-to-face meetings. Moreover, independent of the number of interlocutors, the distance between interlocutors also reduces business travel (Lethiais and Aguiléra, 2007).

Furthermore, interlocutor location affects the geography of business travel and thus, distance traveled. In C. Lassen's 2004 study, 22\% of the trips made by the employees of the University of Aalborg were to countries outside of Europe. In fact, most trips were for congressional and conference purposes, many of which were located in other European countries and North America. By comparison, the same research pointed out that only a small proportion of Hewlett Packard's employees (located in Denmark) travel to non-European destinations, on the one hand because its clients are mostly located in Europe, and on the other, because intra-company contacts are primarily established with other European offices.

A. Aguiléra et al. (2007a) have shown how certain organizational changes can cause a rise in business travel, albeit an often temporary one. In a study of the European offices of an automobile supplier, they explain that reporting procedures have recently been standardized between the various offices, but that this standardization has incurred much local resistance. The monitoring department has called meetings to explain the reasons behind and objectives of the new reporting tool. In addition, the previous four years have seen the specialization of these European production units: essentially, the Spanish unit has specialized in machining and the French unit in assembly. This specialization process can explain an increase in business travel for some technical staff, at least during the transition phase, which is quite long, when technicians had to travel from one site to another to adjust the machines. The variability of industrial strategies also affects the number of business trips, for example when purchases have been 
centralized in only one region in France. The consequence was an increase in longdistance business trips to meet with suppliers in France and Europe.

At a more detailed level of analysis, one must consider that, on the one hand, some departments such as marketing, sales, technical and management inside a given firm are more likely to take business trips (Arnfalk and Kogg, 2003). On the other hand, some forms of work may require frequent face-to-face meetings, whereas others do not. In a recent and very interesting paper, J. Hildrum (2007) tries to differentiate between innovation projects. The author explains that innovation projects differ technologically and relationally, and that these differences go a long way to explaining the contrasting role of face-to-face interaction. More precisely, he emphasizes the influence of two parameters: the first is the existence of brokers, defined as members of the project who are able to mediate communication and knowledge between other members. The author stresses that project groups with a high proportion of brokers require less face-to-face contact. The second important parameter concerns the level of modularity of the technology. Again, innovation projects characterized by highly modular content require fewer face-to-face encounters than less modular innovation projects.

\subsection{Elements that Differentiate Workers}

\subsubsection{From "immobile” to "nomadic" Workers: A Gamut of Possibilities}

Existing empirical studies focus on certain mobile groups, such as highly mobile, internationally traveling employees or "nomadic" workers, for whom working is traveling (Brown and O'Hara, 2003). However, not all workers take business trips. Inside a given firm, some are mobile while others are inevitably immobile (Vecchi and Wickham, 2006). Moreover, it seems that the immobile ones remain more numerous today. 
The Bobuc et al 2006 survey of a representative sample of French employees aged 18 and over shows that more than half $(63 \%)$ never work outside their regular workplace. A. Aguiléra et al's 2007 study of the 2001 Paris Regional Mobility Survey (2007b) also highlights that on a given weekday, 83\% of employees (working outside their place of residence) do not make any business trips (inside the region).

Furthermore, it has been emphasized that there are major differences between the workers traveling for business. The A. Boboc et al. (2006) study divides the $34 \%{ }^{1}$ of mobile French employees into three distinct categories, according to the nature of their workplace (home, regular workplace and irregular workplace). The authors distinguish between the nomadic workers $(9 \%)$, who have only mobile or irregular workplaces, mobile workers (regular workplace + irregular workplace: $15 \%$ or home + regular workplace + irregular workplace: 6\%), and nomadic workers (home + non-regular workplace: 4\%). For example, on any given week day in the Paris region in $2001,10 \%$ of workers went both to their regular workplace and made a business trip, while only $7 \%$ could be considered as being truly nomadic workers i.e. they had made no travel to regular workplace (Aguiléra et al., 2007b).

Furthermore, mobile workers are not affected by business trips in terms of frequency per month or per year, average distance covered, etc. to the same extent. The 1994 French National Travel Survey proves that differences according to professional status are significant, but especially so for long-distance travel: executives are the most frequently mobile, and travel a greater distance per business trip (Massot et al., 2006).

\footnotetext{
${ }^{1} 3 \%$ of the sample failed to respond.
} 


\subsubsection{Hierarchical Position, Income and Gender}

Income, hierarchical position and gender are important (and not totally unrelated) parameters that differentiate between workers in terms of business travel, especially long-distance business travel.

According to the 2001-2002 National Household Travel Survey, one fourth of all business travel in the US over that period was conducted by individuals earning at least $\$ 100,000$ a year. On the contrary, low-income business travelers are very rare (Mallett, 1999). Indeed, the likelihood of travel (especially long-distance business travel) is strongly related to hierarchical position, because it is associated with the transmission of tacit knowledge (Arnfalk and Kogg, 2003; Lian and Denstadli, 2004).

Likewise, men are by far over-represented among business travelers (Frändberg and Vilhelmson, 2003), accounting, for example, for $77 \%$ of US citizens taking business trips in 2002. This over-representation of males in the mobile categories has also been noted by A. Boboc et al. (2006) and, on an intra-regional scale, by A. Aguiléra et al. (2007b). Indeed, males still make up the majority of managers and executives. Moreover, A. Aguiléra et al. (2007b) demonstrate that on an intra-regional level, gender differences are confirmed regardless of professional status. This suggests that women of a given professional status tend to prefer jobs characterized by less frequent business trips, probably because they face more household responsibilities (Turner and Niemeier, 1997; Kwan, 2000).

\section{How do the workers and companies involved perceive business travel?}

\subsection{Business trips and company strategy: many questions, few answers}

While many studies suggest directly or indirectly (making reference to face-toface meetings) that business travel is a key element in today's business relationships, very few investigate if and how the amount of business travel has a direct correlation to 
company strategy, and in particular to decisions made regarding location. Access to transportation is often mentioned as important, but very few analyses explain exactly how it is linked to the need for business travel for certain professional areas requiring a lot of face-to-face contact, such as business services (Aguiléra, 2003).

Business travel is sometimes regarded as a forum for the implementation of cost-cutting strategies. Companies seek to reduce travel costs, not by diminishing the total number of trips, but the cost per trip. One way is to establish a contract with a travel agency and to travel economy class (Van Trommel et al., 1998). It has also been shown that developing videoconferencing was not a satisfactory way to reduce business travel: indeed, those who videoconference the most are also those who travel the most (Arnfalk and Kogg, 2003).

However, companies do not seem to account for the fact that employees often see business travel in a negative light. The companies involved usually view mobility as an important element in their flexibility and reactivity, facilitated or made possible by choosing to locate near transportation infrastructure. Consequently, the physical mobility of employees is largely considered to be a way of achieving industrial strategies motivated by other considerations (such as production costs).

\subsection{Mobile workers, a category "under pressure"?}

Indeed, while professional mobility is generally associated with a high level of education and often regarded as prestigious (Arnfalk and Kogg, 2003), business trips are also often criticized because they are tiring (Westman and Etzion, 2002) and timeconsuming. International travel consumes at least one day and often much more. Mobile employees also lose time in airports, where it is difficult to work between flights (Breure and Van Meele, 2003). Employees are more positive when the distance traveled is lesser and when the means of transport is the train, where it is easier to work and rest 
(Lyons et al., 2007). The study of A. Aguiléra et al. (2007a) stresses that the most mobile business travelers amongst executives tend to defer some of their travel to younger executives, who in general have fewer familial constraints and are not yet "fed up" with mobility.

Also of interest in this study (2007a) is the fact that the executives surveyed believe the number of business trips to have increased from one year to the next; the total amount per person spent on travel costs over the last five years, however, suggests that the number of trips has remained constant. The difference between this reality and the employees' perception of these trips could apparently be explained by the fact that an increased amount of business travel occurs with little notice, particularly to enable conflict resolution. Some of these conflicts are internal to the company, while others are external, concerning problems with clients, particularly with regards to the respect of quality standards. Therefore, many of these business trips could not be planned in advance, because they were decided upon at the last minute in order to "resolve a crisis". It seems that this situation has been a major factor in the feeling that business trips are increasingly frequent as well as more and more unpleasant.

Yet A. Aguiléra et al.' (2007a) also highlight that none of the respondents publicly complain about business travel. The reason given is that the company expressly sees professional mobility as an example of the flexibility and reactivity of its organization and members. C. Lassen (2004) notes a similar situation for Hewlett Packard in Denmark, who exerted 'institutional pressure' to be mobile.

\section{Conclusion}

It is common knowledge that the development of ICTs and transportation infrastructure (and the associated decrease in the cost of transportation) have made it 
possible to stay in contact with remote partners: some kinds of relationships do not require face-to-face contact, while others, often more complex or strategic, can be maintained through a combination of ICTs and (more or less frequent) face-to-face meetings (Charlot and Duranton, 2006; Torre and Rallet, 2005). This complementary relationship between mediated and non-mediated contacts is largely accepted and well explained in the literature. The consequences of such developments in terms of physical (business) travel, however, have yet to be considered in the same depth.

The role of business travel in contemporary economic activity is an important area of research. This paper has argued that an analysis of recent literature can help us understand the motives for business travel and identify mobile workers. It is particularly strong on factors related to the company organization and industrial strategies, as well as client relationships. This paper has also stressed that ICTs are a strong complement to, and even incentive for, business trips insofar as they allow organizational strategies necessitating remote teamwork.

Communication methods (both mediated and face-to-face) are thus complementary rather than substitutes for one another. This does not mean, of course, that there is no relationship between them, but rather that further ICT development will not lead to a dramatic reduction in face-to-face contact and business travel. Some aspects of this complementarity may lead to an increase in business travel, others to a decrease. On the one hand, the development of ICTs favors the creation of networks in which members are not located close to each other, which therefore may lead to the need for travel. The use of ICTs can also help and even allow the maintenance of relationships built between geographically close partners when one of them changes location. On the other hand, ICT improvement can mean that face-to-face contact is necessary for only the most complex interactions, bringing about a relative decrease in 
business travel (Charlot and Duranton, 2006), particularly when the participants are located very far from each other (for instance on two different continents). Due to complex reorganizations that researchers do not yet fully understand, but that constitute a crucial question of research, business travel can thus increase, decrease, or even remain stable on a smaller scale (for each individual department or employee of a given firm), even while major changes may occur in the amount of travel required.

The evolution of business travel should also be examined in terms of its environmental impact (Hoyer and Naess, 2001), especially since it constitutes a significant portion of air traffic (Bender and Stephenson, 1998; Mason, 2000; Mason and Gray, 1995). In Norway in 2005, for example, 28\% of air travel was business related.

Business travel should also be examined with reference to changes in the relationship between family and working life (Belton and De Coninck, 2006; Espino et al., 2002; Gustafson, 2006). Employees' ability to organize their own mobility in a way that minimizes its more negative effects therefore constitutes an important area of research. 


\section{References}

Aguiléra, A. (2003) Service Relationship, Market Area and the Intrametropolitan Location of Business Services. The Service Industries Journal, 23(1), 43-58.

Aguiléra, A., De Coninck, F. and Hauchard, P. (2007a) Le rôle des déplacements professionnels dans les entreprises multi-établissements. Le cas d'un fournisseur de l'automobile. Recherche, Transports, Sécurité, 24(96), 195-209.

Aguiléra, A. Massot, M.H. and Proulhac, L. (2007b) Work-related travel and the organization of daily mobility. A case study. Conference of the European Regional Science Association (ERSA), Paris.

Amin, A. (2002) Spatialities of Globalization. Environment and Planning A, 34, 385399.

Andersson, M. and Ejermo, E. (2005) How does accessibility to knowledge sources affect the innovativeness of corporations? Evidence from Sweden. The Annals of Regional Science, 39(4), 741-765.

Andersson, M., and Karlsson, C. (2004) The Role of Accessibility for the Performance of Regional Innovation Systems. CESIS Electronic Working Paper Series, 9.

Arnfalk, P. and Kogg, B. (2003) Service transformation- managing a shift from business travel to virtual meetings. Journal of Cleaner Production, 11(8), 859-872.

Balconi, M. Pozzali, A. and Viale, R. (2007) The "codification debate" revisited: a conceptual framework to analyze the role of tacit knowledge in economics. Industrial and Corporate Change, in press.

Barley, S.R. and Kunda, G. (2001) Bringing Work Back In. Organization Science, 12(1), 76-95. 
Bathelt, H. Malmberg, A. and Maskell, P. (2004) Clusters and knowledge: local buzz, global pipelines and the process of knowledge creation. Progress in Human Geography, 28(1), 31-56.

Belton, L. and De Coninck, F. (2006) Des frontières et des liens. Les topologies du privé et du professionnel pour les travailleurs mobiles. Réseaux, 140, 67-100.

Bender, A.R. and Stephenson, F.J. (1998) Contemporary issues affecting the demand for business air travel in the United States. Journal of Air Transport Management, 4, 99-109.

Boboc, A., Dhaleine, L. and Maillard, A. (2006) Travailler, se déplacer et communiquer : premiers résultats d'enquête. Réseaux, 140, 133-158.

Boden, D. and Molotch, H. (1994) The compulsion of proximity. In Friedland, R and Boden D. (Eds), NowHere: Space, time and modernity, UCLA Press, Berkeley, CA.

Breure, A. and Van Meel, J. (2003) Airport offices: facilitating nomadic workers. Facilities, 21(7/8), 175-179.

Brousseau, E. and Rallet, A. (1997) Le rôle des technologies de l'information et de la communication dans les changements organisationnels. Economie de la connaissance et organisation. Entreprise, Territoires, Réseaux eds B. Guilhon, P. Huard,, M. Orillard and J.B. Zimmerman J.B., L'Harmattan, Paris.

Brown, B. and O'Hara, K. (2003) Place as a practical concern of mobile workers. Environment and Planning A, 35 (9), 1565-1587.

Charlot, S. and Duranton, G. (2006) Cities and workplace communication. Some quatitative french evidence. Urban Studies, 43(8), 1365-1394. 
Espino, C.M., Sundstrom, S.M., Frick, H.L., Jacobs, M. and Peters, M. (2002) International business travel: impact on families and travelers. Occupational and Environmental Medicine, 59, 309-322.

Frändberg, L. and Vilhelmson, B. (2003) Personal mobility: a corporeal dimension of transnationalisation. The case of long-distance travel from Sweden. Environment and Planning A, 35, 1751-1768.

Gallaud, D. and Torre, A. (2005) Geographical proximity and the diffusion of knowledge: The case of SMEs in biotechnology. Rethinking Regional Innovation eds G. Fuchs, P. Shgapira and A. Koch, Dordrecht: Kluwer.

Gallié, E.P. and Guichard, R. (2005) Do collaboratories mean the end of face to face interactions? An evidence from the ISEE Project. Economics of Innovation and New Technology, 14(7), 517-532.

Gaspar, J. and Glaeser E. L. (1998) Information Technology and the Future of Cities. Journal of Urban Economics, 43, 136-156.

Gustafson, P. (2006) Work-related travel, gender and family obligations. Work, Employment and Society, 20(3), 513-530.

Handy, C. (1995) Trust and Virtual Organization. Harvard Business Review, 73(3), 4050.

Haynes, P., Vecchi, A. and Wickham, J. (2005) Flying around the globe and bringing business back home? European Sociological Association Conference, Poland.

Hildrum, J. (2007) When is frequent face-to-face contact necessary in innovation? A comparative study of two distributed product development projects. Economics of Innovation and New Technology, 16(6), 467-484. 
Hoyer, K.G. and Naess, P. (2001) Conference Tourism. A Problem for the Environment, as well as for Research? Journal of Sustainable Tourism, 9(6), 451-470.

Hugoson, P. (2001) Interregional Business Travel and the Economics of Business Interaction. Dissertation Series $n^{\circ} 009$, Jönköping International Business School.

Kirkman, B.L. Rosen, B., Tesluk, P.E. and Gibson, C.B. (2004) The impact of team empowerment on virtual team performance: the moderating role of face-to-face interaction. Academy of Management Journal, 47(2), 175-192.

Kwan, M.P. (2000) Gender, the Home-work Link and Space-time Patterns of NonEmployment Activities. Economic Geography, 75(4), 370-394.

Larsen, J. Urry, J. and Axhausen, K.W. (2007) Networks and Tourism. Mobile Social Life. Annals of Tourism Research, 34(1), 244-262.

Lassen, C. (2004) Work travel, knowledge industries, and the environment. Working Paper, University of Aalborg.

Lethiais, V. and Aguiléra, A. (2007) Les relations de coopération inter-entreprises : TIC versus face à face. International Conference on Online services, Paris, 13-14 décembre. Lian, J.I. and Denstadli, J.M. (2004) Norwegian business air-travel-segments and trends. Journal of Air Transport Management, 10, 109-118.

Lorentzon, S. (2003) Changes in the Flows and Means of Information Exchange: Business Uses of ICT in Sweden in the 1990s. Journal of Urban Technology, 10(1), 89110.

Lundvall, B.A. and Johnson, B. (1994) The Learning Economy. Industry and Innovation, 1 (2), 23-42. 
Lyons, G. Jain, J. and Holley, D. (2007) The use of travel time by rail passengers in Great Britain. Transportation Research Part A, 41, 107-120.

Mallett, W.J. (1999) Long-Distance Travel by Low-Income Households. Transportation Research Board Conference, Washington DC.

Mason, K.J. (2000) The propensity of business travelers to use low cost airlines. Journal of Transport Geography, 8, 107-119.

Mason, K.J. and Gray, R. (1995) Short haul business travel in the European Union: a segmentation profile. Journal of Air Transport Management, 2(3/4), 197-205.

Massot, M.H, Aguiléra, A., Crague, G., De Coninck, F. and Proulhac, L. (2006) Les mobilités liées au travail. Rapport de recherche pour le PREDIT, mars.

Ota, M. and Fujita, M. (1993) Communication technologies and spatial organization of multi-unit firms in metropolitan area. Regional Science and Urban Economics, 23, 695729.

Rallet, A and Burmeister, A. (2002) Recherche sur la complémentarité des télécommunications et des transports et ses effets sur la localisation des activités et la mobilité des personnes. Rapport de recherche pour la DRAST, octobre.

Rallet, A. and Torre, A. (2000) Is Geographical Proximity Necessary in the Innovation Networks in the era of Globalization? GeoJournal, 49, 373-380.

Ramirez-Pasillas, M. (2006) Tradeshow Fairs: Hotspots for building temporary proximity and creating potential for firms upgrading. Proceedings of the Fifth Proximity Conference, Bordeaux, june.

Turner, T. and Niemeier D. (1997) Travel to work and household responsibility: new evidence. Transportation, 24, 397-419. 
Torre, A. and Rallet, A. (2005) Proximity and Localization. Regional Studies, 39(1), 4759.

Ughetto, P. Besucco, N. Tallard, M. and Du Tertre, C. (2002) La relation de service: une tension vers un nouveau modèle de travail? Revue de l'IRES, 39(2), 1-29.

Urry, J. (2002) Mobility and proximity, Sociology, 30(2), 255-274.

Van Trommel, M.F. Simonian, P.T. Potter, H.G. Wickiewicz, T.L. Roy, J. and Filialtrault, P. (1998) The impact of new business practices and information technologies on business air travel demand. Journal of Air Transport Management, 4(2), 77-86.

Vecchi, A. and Wickham, J. (2006) Clusters and Pipelines, Commuters and Nomads: Business Travel in the Irish Software Industry. Proceedings of the Fifth Proximity Conference, Bordeaux, june.

Westman, M. and Etzion, D. (2002) The Impact of Short Overseas Business Trips on Job stress and Burnout. Applied Psychology: An International Review, 51(4), 582-592.

Wickström, S. (1995) The customer as co-producer. European Journal of Marketing, 30(4), 6-19. 